\title{
Pengaruh penanaman modal dalam negeri (PMDN), penanaman modal asing (PMA), ekspor dan impor terhadap pertumbuhan ekonomi Provinsi Jambi
}

\author{
Dian Setia Ningsih, Haryadi*, Siti Hodijah \\ Prodi Magister Ilmu Ekonomi Program Pascasarjana Universitas Jambi \\ *E-mail korespodensi: haryadikamal@gmail.com
}

\begin{abstract}
This study aims to analyze the development of PMDN, PMA, Exports, Imports, and Economic Growth in Jambi province and to analyze the influence of PMDN, PMA, Exports, and Imports on economic growth in Jambi province. The analysis model used is the Autoregressive Distributed Lag (ARDL). The results showed that in the short term PMDN had a significant negative effect on economic growth. PMA has a positive and significant effect on economic growth. Exports have a significant positive effect on economic growth. In the long term, PMDN has a positive and significant effect on economic growth. PMA has a negative and significant effect on economic growth. The export variable has a positive and significant effect on economic growth. And imports have a positive but insignificant effect on economic growth. It is hoped that economic growth will continue to increase from year to year, so the government must play an important role in increasing economic activities that have existing potentials so that the people's income is high which also reduces poverty and inequality that occurs.
\end{abstract}

Keywords: Economic growth, Domestic investment (PMDN), Foreign investment (PMA), Export, Import,Autoregressive distributed lag (ARDL)

\begin{abstract}
Abstrak
Penelitian ini bertujuan untuk menganalisis perkembangan PMDN, PMA, Ekspor, Impor dan Pertumbuhan Ekonomi di provinsi Jambi dan untuk menganalisis pengaruh PMDN, PMA, Ekspor dan Impor terhadap pertumbuhan ekonomi di provinsi Jambi. Model analisis yang digunakan adalah Autoregressive Distributed Lag (ARDL). Hasil penelitian menunjukkan bahwa dalam jangka pendek PMDN berpengaruh negatif signifikan terhadap pertumbuhan ekonomi. PMA berpengaruh positif dan signifikan terhadap pertumbuhan ekonomi. Ekspor berpengaruh positif signifikan terhadap pertumbuhan ekonomi. Dalam jangka panjang PMDN berpengaruh positif dan signifikan terhadap pertumbuhan ekonomi. PMA berpengaruh negatif dan signifikan terhadap pertumbuhan ekonomi. Variabel ekspor berpengaruh positif dan signifikan terhadap pertumbuhan ekonomi. Dan impor berpengaruh positif tetapi tidak signifikan terhadap pertumbuhan ekonomi. Diharapkan pertumbuhan ekonomi terus meningkat dari tahun ke tahunnya maka pemerintah harus berperan penting dalam rangka meningkatkan kegiatan ekonomi yang memiliki potensi-potensi yang ada sehingga pendapatan masyarakat tinggi yang juga mengurangi kemiskinan dan ketimpangan yang terjadi.
\end{abstract}

Kata kunci : Pertumbuhan ekonomi, Penanaman modal dalam negeri (PMDN), Penanaman modal asing (PMA), Ekspor, Impor, Autoregressive distributed lag (ARDL) 


\section{PENDAHULUAN}

Pertumbuhan ekonomi merupakan perkembangan kegiatan dalam perekonomian yang menyebabkan barang dan jasa yang diproduksi dalam masyarakat bertambah (Sukirno,2011). Pertumbuhan ekonomi yang tinggi hal yang sangat diinginkan semua negara maupun daerah. Menurut Arsyad (2010) ada 4 (empat) faktor utama yang mempengaruhi pertumbuhan ekonomi suatu masyarakat (negara) antara lain akumulasi modal, pertambahan penduduk, kemajuan teknologi dan sumberdaya institusi (sistem kelembagaan).

Investasi yang merupakan bagian cukup penting untuk mempercepat perkembangan perekonomian suatu negara atau daerah. Investasi sendiri di Indonesia memiliki investasi yang di jalankan pemerintah dan juga ada investasi yang di miliki oleh pihak swasta. Investasi pemerintah berasal dari tabungan pemerintah serta yang berasal dari bantuan luar negeri. Sementara investasi swasta ini di bedakan antara investasi asing yang sering disebut Penanaman Modal Asing (PMA) dan investasi dalam negeri atau Penanaman Modal Dalam Negeri (PMDN). Dalam pembangunan ekonomi di suatu negara atau daerah seperti di provinsi Jambi investasi PMDN dan PMA memiliki peranan penting dalam menentukan jumlah output dan pendapatan. Hal inilah yang membuat investasi PMDN dan PMA di provinsi Jambi harus dapat di tingkatkan dari tahun ke tahun.

Selain dari investasi, pertumbuhan ekonomi Indonesia juga didukung dari sektor perdagangan luar negeri, yaitu ekspor dan impor. David Ricardo telah menerangkan perlunya perdagangan internasional dalam mengembangkan suatu perekonomian, serta mengenai keuntungan yang dapat diperoleh dari spesialisasi dan perdagangan antar negara (Sukirno, 2011). Kegiatan ekspor impor didasari oleh kondisi bahwa setiap negara memiliki karakteristik sumber daya masing-masing dan tentunya karakteristik tersebut berbeda antara satu negara dengan negara lainnya. Ekspor merupakan salah satu tolak ukur penting untuk mengetahui seberapa besar pertumbuhan ekonomi di suatu negara. Ekspor telah menjadi fokus utama pemerintah dalam memacu pertumbuhan ekonomi seiring dengan berubahnya strategi industrialisasi dari penekanan pada substitusi impor ke promosi ekspor. Dengan adanya impor, pemenuhan kebutuhan suatu negara dapat terpenuhi. Impor bermanfaat untuk mengisi kekosongan barang atau jasa yang tidak dapat diproduksi oleh negara itu sendiri. Dengan memperhatikan pentingnya peran pertumbuhan ekonomi terhadap stabilitas perekonomian suatu daerah terutama di provinsi Jambi maka dalam penelitian ini penulis mengambil judul "Pengaruh Investasi PMDN, PMA, Ekspor dan Impor Terhadap Pertumbuhan Ekonomi Di Provinsi Jambi".

Perumusan Masalah dalam penelitian ini yaitu (1) Bagaimana perkembangan PMDN, PMA, Ekspor, Impor dan Pertumbuhan Ekonomi di provinsi Jambi? (2) Bagaimana pengaruh PMDN, PMA, Ekspor dan Impor terhadap Pertumbuhan Ekonomi di provinsi Jambi?. Tujuan dalam penelitian ini yaitu (1) Untuk menganalisis perkembangan PMDN, PMA, Ekspor, Impor dan Pertumbuhan Ekonomi di provinsi Jambi. (2) Untuk menganalisis pengaruh PMDN, PMA, Ekspor dan Impor terhadap Pertumbuhan Ekonomi di provinsi Jambi.

\section{METODE}

\section{Jenis dan sumber data}

Penelitian ini memiliki cakupan daerah di provinsi Jambi yang menggunakan data sekunder runtun waktu (time series) periode 1993-2018. Adapun data yang digunakan dalam penelitian ini adalah Pertumbuhan Ekonomi, Penanaman Modal Dalam Negeri (PMDN), Penanaman Modal Asing (PMA), Ekspor dan Impor. Dari berbagai jenis data yang di gunakan dalam penelitian di atas di peroleh dari berbagai sumber dalam bentuk laporan dan publikasi. Publikasi- publikasi tersebut antara lain dari Badan Pusat 
Statistik (BPS ) provinsi Jambi, Badan Koordinasi Penanaman Modal dan Pusat Perizinan Terpadu (BKPMPPT) provinsi Jambi dan Bank Indonesia (BI) provinsi Jambi.

\section{Metode analisis data}

Metode analisis yang digunakan dalam penelitian ini terdiri dari dua metode analisis yaitu metode analisis deskriptif dan metode analisis kuantitatif. Metode deskriptif ini merupakan metode yang digunakan untuk membuat gambaran secara sistematis dan faktual tentang fakta, gejala dan fenomena dari setiap variabel penelitian. Metode analisis data kuantitatif yaitu nilai data yang dinyatakan dalam skala numerik. Untuk masalah kedua maka menggunakan analisis kuantitatif model ekonometrika, digunakan metode analisis regresi linier berganda dengan pendekatan model ARDL (Autoregressive Distributed Lag) yang dapat melihat hubungan antar variabel dengan faktor penentunya dilakukan untuk menelaah pengaruh PMDN, PMA, Ekspor dan Impor di provinsi Jambi, sebagai alat pengolahan data dengan menggunakan program

Eviews 9.

\section{Autoregressive distributed lag (ARDL)}

Penelitian ini menerapkan pendekatan Autoregressive Distributed Lag (ARDL) yang diperkenalkan oleh Pesaran, Shin, \& Smith (2001) untuk menguji keberadaan kointegrasi antar variabel dan juga untuk memperkirakan koefisien jangka panjang dan jangka pendek dari variabel-variabel tersebut. Dalam menentukan persamaan regresi, masing-masing variabel akan diestimasi dengan memasukkan lag jangka panjang dan jangka pendek hingga ditemukan model yang terbaik, yaitu model dengan variabel yang signifikan. Untuk menghasilkan model terbaik ini, digunakan metode general to specific, yaitu dengan menghilangkan variabel yang tidak signifikan. Dengan metode ini, satu per satu variabel yang memiliki nilai probabilitas yang tidak signifikan dan paling besar akan dihilangkan. Hubungan jangka panjang dapat dianalisis dengan menggunakan persamaan ARDL sebagai berikut:

$$
P E_{t}=\beta_{0}+\sum_{t=1}^{p} \beta_{1} P M D N_{t-i}+\sum_{t=1}^{p} \beta_{2} P M A_{t-i}+\sum_{t=1}^{p} \beta_{3} E K S_{t-i}+\sum_{t=1}^{p} \beta_{4} I M P_{t-i}+\mu_{t}
$$

Apabila terdapat hubungan jangka panjang di antara variabel, maka hubungan jangka pendek variabel dapat diselidiki dengan vector ECM sebagai berikut:

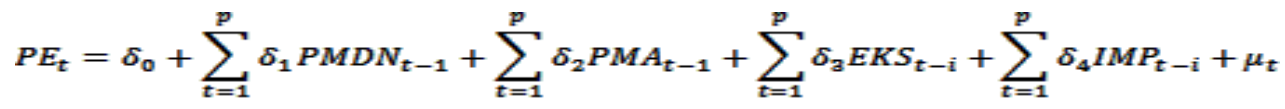

Error Correction Term (ECT) mengindikasikan kecepatan penyesuaian dan menunjukkan seberapa cepat variabel kembali ke ekuilibrium jangka panjang. ECT seharusnya memiliki koefisien yang signifikan secara statistika dan memiliki nilai negatif. ECT diperoleh dari Persamaan (3), sedangkan penjelasan lebih lanjut mengenai penurunan variabel ECT dapat dilihat pada lampiran. Kesesuaian atau goodness of fitdari model ARDL dapat dilihat melalui tes stabilitas seperti Cumulative Sum of Recursive Residuals (CUSUM) dan Cumulativesum of Squares of Recursive Residuals (CUSUMSQ). Uji stabilitas digunakan untuk mendeteksi stabilitas parameter dalam jangka panjang dan jangka pendek. Pesaran et al.(2001) berpendapat bahwa CUSUM dan CUSUMSQ merupakan suatu pengujian yang cukup baik untuk menguji stabilitas model ini. Grafik CUSUM yang signifikan pada tingkat kepercayaan 5\% mengindikasikan adanya stabilitas parameter. 


\section{Analisis deskriptif}

\section{Perkembangan pertumbuhan ekonomi Provinsi Jambi Tahun 1993-2018}

Sebelum krisis ekonomi melanda Indonesia pertumbuhan ekonomi Indonesia cukup tinggi dari tahun ke tahun termasuk di provinsi Jambi. Namun pertumbuhan ekonomi yang tinggi seharusnya mampu disikapi sehingga tidak lupa untuk menganalisis faktor-faktor apa sebenarnya yang menjadi pendorong utama tinggginya pertumbuhan ekonomi. Menurunnya pertumbuhan ekonomi akibat dari adanya krisis terlihat lebih parah pada tahun berikutnya dimana pertumbuhan ekonomi mencapai hingga pertumbuhan minus. Upaya pemulihan perekonomian menjadi langkah awal untuk kembali membangun perekonomian yang kuat dan stabil. Pertumbuhan ekonomi daerah yang ditunjukkan oleh PDRB atas harga konstan merupakan gambaran mengenai pendapatan daerah yang diciptakan oleh faktor-faktor produksi baik berupa barang maupun jasa.

Perkembangan PDRB provinsi Jambi dari tahun 1993-2018 mengalami peningkatan setiap tahunnya dengan nilai pertumbuhan sebesar $23,37 \%$. Pertumbuhan yang paling tinggi terjadi di tahun 2015 sebesar 436,43\% hal ini di karenakan memadainya infrastruktur yang telah dilakukan pada tahun sebelumnya yang membuat jalannya perekonomian di provinsi Jambi membaik dari perbaikan jalan maupun informasi. Hal ini membuat lancarnya kegiatan ekonomi dan menyerap tenaga kerja sehingga mengurangi pengangguran yang terjadi. Dan pertumbuhan terendah terjadi di tahun 1998 sebesar $-5,42 \%$, hal ini sebagai akibat dari krisis ekonomi yang terjadi pada tahun sebelumnya dan merupakan pertumbuhan ekonomi terendah. Keadaan ini tidak lain dikarenakan rapuhnya infrastruktur pasar karena melemahnya sistem akuntasi dan sistem hukum sehingga menyebabkan distorsi dan gangguan transformasi informasi pasar.

\section{Perkembangan PMDN Provinsi Jambi}

Provinsi Jambi memiliki daya tarik investasi tersendiri untuk para investor dalam menanamkan modalnya. Hal ini terlihat selama tahun 1993-2018 investasi PMDN di Provinsi Jambi, jumlah investasi PMDN yang direalisasikan mengalami perkembangan yang fluktuasi dari tahun ke tahunnya., yang mengindikasikan bahwa perkembangan ekonomi Provinsi Jambi telah mendapat perhatian dari para penanam modal. Perkembangan PMDN di provinsi Jambi tahun 1993-2018 yang di realisasikan mengalami fluktuatif cenderung meningkat dari tahun ke tahunnya. Rata-rata perkembangan realisasi PMDN provinsi Jambi sebesar 11,1\%. Perkembangan realisasi PMDN tertinggi terjadi di tahun 1997 sebesar 149,8\%, ini menandakan tumbuhnya minat penanam modal dalam negeri untuk berperan dalam menanamkan modalnya baik diberbagai sektor. Sedangkan perkembangan realisasi PMDN yang paling terendah terjadi ditahun 2017 sebesar $-88,1 \%$. Hal ini dikarenakan jumlah realisasi PMDN yang dari segi angkanya turun dari tahun sebelumnya sebab ditahun ini nilai realisasi yang dicatat sesuai penanam modal yang melakukan pelaporan perizinan untuk usahanya.

\section{Perkembangan PMA Provinsi Jambi Tahun 1993-2018}

Investasi asing atau yang lebih dikenal sebagai PMA (Penanaman Modal Asing) sebagai salah satu asset yang yang menunjang pembangunan nasional karena pada hakekatnya antara investasi dan pendapatan nasional demikian eratnya dan penting, karena bila adanya konduksi yang menyebabkan berkurangnya konsumsi, maka pendapatan makin banyak. Adanya investasi asing di dalam masyarakat pertama-tama akan sangat membantu dan menambah kesempatan kerja, sehingga pendapatan masyarakatpun bertambah begitu juga dalam jaringan yang lebih luas dimana akan menambah pendapatan nasional suatu negara. Penanaman Modal Asing (PMA) berada 
di Indonesia bukan hanya di pusat ibukota tetapi juga investor asing menanamkan modalnya diberbagai daerah termasuk di provinsi Jambi. Perkembangan realisasi PMA provinsi Jambi selama periode 1993-2018 mengalami fluktuatif dengan nilai rata-rata perkembangan sebesar $475 \%$. Perkembangan yang paling tinggi terjadi di tahun 1995 sebesar 10569,8\% dengan nilai realisasi sebesar US\$ 803.222 ribu, hal ini dikarenakan adanya ketertarikan investor asing untuk menanamkan modalnya di provinsi Jambi. Sedangkan perkembangan realisasi PMA terendah terjadi di tahun 1997 sebesar -92,1\% dengan nilai realiasinya sebesar US\$ 17.665 ribu, ini dikarenakan pada tahun ini awal terjadinya krisis moneter yang dialami oleh Indonesia yang berdampak pada menurunnya investasi asing.

\section{Perkembangan ekspor Provinsi Jambi Tahun 1993-2018}

Ekspor mencerminkan aktivitas perdagangan antar bangsa yang dapat memberikan dorongan dalam dinamika pertumbuhan perdagangan internasional, sehingga suatu negara-negara yang sedang berkembang kemungkinan untuk mencapai kemajuan perekonomian setaraf dengan negara-negara yang lebih maju atau sebaliknya. Kenaikan ekspor akan berakibat terhadap peningkatan pendapatan atau devisa bagi suatu negara dan akan meningkatkan permintaan terhadap barang dan jasa didalam negeri. Indonesia yang terdiri dari berbagai daerah juga melakukan ekspor termasuk provinsi Jambi.

Tabel 1. Perkembangan PMDN, PMA, ekspor dan impor Provinsi Jambi

\begin{tabular}{|c|c|c|c|c|}
\hline Tahun & $\begin{array}{c}\text { Perkembangan PMDN } \\
(\%)\end{array}$ & $\begin{array}{c}\text { Perkembangan } \\
\text { PMA (\%) }\end{array}$ & $\begin{array}{c}\text { Perkembangan } \\
\text { Ekspor }(\%)\end{array}$ & $\begin{array}{c}\text { Perkembangan } \\
\text { Impor (\%) }\end{array}$ \\
\hline 1993 & - & - & & \\
\hline 1994 & 31.5 & 502.2 & 28.18 & 1.02 \\
\hline 1995 & 11.5 & 10569.8 & 24.19 & -55.36 \\
\hline 1996 & -32.0 & -72.2 & 2.55 & -22.17 \\
\hline 1997 & 149.8 & -92.1 & -11.35 & 11.83 \\
\hline 1998 & 31.2 & 115.8 & 0.05 & 36.90 \\
\hline 1999 & -2.5 & -69.1 & -12.66 & -63.85 \\
\hline 2000 & 28.2 & 582.7 & 2.36 & -3.88 \\
\hline 2001 & 4.4 & 12.8 & 12.21 & 31.72 \\
\hline 2002 & 5.6 & -1.6 & -18.64 & -2.46 \\
\hline 2003 & 4.0 & -5.3 & 12.80 & 60.11 \\
\hline 2004 & 1.9 & 10.1 & -3.91 & -87.39 \\
\hline 2005 & 3.0 & 7.0 & -7.11 & 1014.66 \\
\hline 2006 & 3.9 & 49.2 & 100.24 & 40.24 \\
\hline 2007 & 0.0 & 0.1 & 28.90 & 9.90 \\
\hline 2008 & -3.1 & 62.4 & 10.06 & -18.25 \\
\hline 2009 & 11.3 & 10.7 & -31.64 & -36.78 \\
\hline 2010 & 13.8 & 68.2 & 82.93 & 173.10 \\
\hline 2011 & 36.0 & 38.6 & 60.18 & -28.99 \\
\hline 2012 & 30.9 & 33.2 & -22.58 & -33.00 \\
\hline 2013 & 26.3 & 18.9 & 44.37 & 128.96 \\
\hline 2014 & 12.9 & 8.9 & -35.87 & -28.43 \\
\hline 2015 & 12.5 & 11.1 & -37.00 & -44.61 \\
\hline 2016 & 12.3 & 0.1 & -9.51 & 19.52 \\
\hline 2017 & -88.1 & 6.4 & 25.62 & -51.34 \\
\hline 2018 & -26.6 & 8.1 & -1.54 & 35.56 \\
\hline Rata-rata & 11.1 & 475.0 & 9.71 & 43.48 \\
\hline
\end{tabular}

Sumber: Badan Pusat Statistik dan Badan Koordinasi Penanaman Modal dan Pusat Perizinan Terpadu, 2020 (diolah) 
Perkembangan ekspor provinsi Jambi tahun 1993-2018 mengalami fluktuatif setiap tahunnya dengan rata-rata sebesar $9,71 \%$. Perkembangan ekspor tertinggi terjadi di tahun 2006 sebesar 100,24\%, hal ini dikarenakan mulai tahun ini pemerintah daerah memberikan himbauan supaya distribusi ekspor langsung melalui pelabuhan Jambi dan tidak seperti tahun sebelumnya yang distribusinya melalui pelabuhan di provinsi lain. Produk yang dapat di distribusikan langsung melalui pelabuhan provinsi Jambi yaitu produk karet, CPO dan batu bara. Potensi berbagai komoditas tersebut merupakan primadona perdagangan kawasan dimasa mendatang. Dan perkembangan ekspor terendah dialami di tahun 2015 sebesar 37\%, ini disebabkan meningkatnya kegiatan impor di provinsi Jambi sehingga kegiatan ekspor mengalami penurunan.

\section{Perkembangan impor Provinsi Jambi Tahun 1993-2018}

Aktivitas impor mempunyai dampak terhadap perekonomian suatu negara dan masyarakatnya. Untuk melindungi produsen yang lemah di dalam negeri, biasanya suatu negara membatasi jumlah (kuota) impor. Selain untuk melindungi produsen dalam negeri, pembatasan impor juga mempunyai dampak yang lebih luas terhadap perekonomian suatu negara. Untuk memenuhi kebutuhannya domestiknya, Provinsi Jambi belum mampu seratus persen menghasilkan barang dan jasa sendiri, ada beberapa komoditi seperti mesin pengolah pulp/kertas, bahan kimia dan beberapa perkakas rumah tangga yang harus mendatangkannnya dari luar negeri. Untuk mengatasi masalah ini, salah satu jalan keluarnya dengan mengadakan impor.

Perkembangan nilai impor provinsi Jambi tahun 1993-2018. Perkembangan nilai impor di provinsi Jambi setiap tahun mengalami fluktuatif dari tahun ke tahun. Rata-rata perkembangan nilai impor provinsi Jambi sebesar 43,48 persen. Perkembangan nilai impor tertinggi provinsi jambi terjadi tahun 2005 sebesar1014,66 persen dikarenakan terjadinya peningkatan kegiatan impor yang dilakukan oleh berbagai sektor dalam memenuhi kebutuhan bahan yang mereka perlukan. Perkembangan nilai ekpor terendah terjadi di tahun 2004, sebesar -87,39 hal ini dikarenakan impor tidak berjalan dengan baik. Ditahun 1994 perkembangan nilai impor sebesar1,05 persen tetapi tahun 1995 menurun menjadi $-55,36$ persen.

\section{HASIL DAN PEMBAHASAN}

\section{Uji akar unit (Unit roots test)}

Untuk menguji stasioneritas dalam penelitian ini menggunakan uji Augmented Dickey-Fuller $(A D F)$. Berdasarkan hasil uji akar -akar unit (unit root test) dengan metode ADF dapat dilihat sebagai berikut :

Tabel 2. Nilai uji akar unit dengan metode uji ADF pada tingkat level

\begin{tabular}{cccccc}
\hline Variabel & $\begin{array}{c}\text { Nilai ADF } \\
\text { Test }\end{array}$ & $\begin{array}{c}\text { Nilai Kritis } \\
\text { Mackinnon } \\
\mathbf{5 \%}\end{array}$ & $\begin{array}{c}\text { Nilai Kritis } \\
\text { Mackinnon } \\
\mathbf{1 0 \%}\end{array}$ & Probabilitas & Keputusan \\
\hline PE & $-2,544694$ & $-2,991878$ & $-2,635542$ & 0,1181 & Tidak Stasioner \\
PMDN & $-1,887031$ & $-2,986225$ & $-2,632604$ & 0,3326 & Tidak Stasioner \\
PMA & 1,337037 & $-2,998064$ & $-2,638752$ & 0,9980 & Tidak Stasioner \\
EKS & $-1,747095$ & $-2,986225$ & $-2,632604$ & 0,3966 & Tidak Stasioner \\
IMP & $-3,075887$ & $-2,986225$ & $-2,632604$ & 0,0415 & Stasioner \\
\hline
\end{tabular}

Sumber : Data diolah, 2020

Dari Tabel 2 dapat diketahui bahwa dalam pengujian stasioneritas melalui uji ADF, hanya variabel impor yang stasioner pada tingkat level. Sedangkan variabel Penanaman Modal Dalam Negeri (PMDN), Penanaman Modal Asing (PMA), 
ekspor(EKS), Impor (IMP) tidak stasioner pada tingkat level. Dari hasil pengujian ini menunjukkan diperlukannya pengujian derajat integrasi.

\section{Uji derajat integrasi}

Uji derajat integrasi dilakukan untuk mengetahui pada tingkat diferensi ke berapa semua variabel telah stasioner. Dalam penelitian ini uji derajat integrasi juga menggunakan uji Augmented Dickey-Fuller (ADF).

Tabel 3. Nilai uji akar unit dengan metode uji ADF pada tingkat pertama

\begin{tabular}{cccccc}
\hline Variabel & $\begin{array}{c}\text { Nilai ADF } \\
\text { Test }\end{array}$ & $\begin{array}{c}\text { Nilai Kritis } \\
\text { Mackinnos 5\% }\end{array}$ & $\begin{array}{c}\text { Nilai Kritis } \\
\text { Mackinnos } \\
\mathbf{1 0 \%}\end{array}$ & Probabilitas & Keputusan \\
\hline PE & $-7,719045$ & $-2,991878$ & $-2,635542$ & 0,0000 & Stasioner \\
PMDN & $-5,029302$ & $-3,029970$ & $-2,655194$ & 0,0008 & Stasioner \\
PMA & $-5,682813$ & $-2,998064$ & $-2,638752$ & 0,0001 & Stasioner \\
EKS & $-5,553171$ & $-2,991878$ & $-2,635542$ & 0,0001 & Stasioner \\
IMP & $-5,835430$ & $-2,998064$ & $-2,638752$ & 0,0001 & Stasioner \\
\hline
\end{tabular}

Sumber :Data diolah, 2020

Dari Tabel 3 dapat diketahui bahwa dalam pengujian stasioneritas melalui uji ADF, semua variabel stasioner. Sehingga dapat disimpulkan bahwa semua variabel telah stasioner pada diferensi pertama dan siap digunakan dalam analisis Autoregressive Distributed Lag (ARDL).

\section{Uji penentuan lag optimal}

Pada penelitian ini kriteria pemilihan lag secara otomatis telah dilakukan oleh EViews. Besarnya lag yang dipilih ditentukan oleh nilai Akaike Information Criteria (AIC ) terkecil. Kriteria dengan nilai AIC terkecilah yang paling baik dari 20 model terbaik yang ditawarkan oleh kriteia AIC. Berdasarkan penelitian yang dilakukan bahwa kriteria yang terpilih dalam penelitian ini yaitu ARDL $(3,3,3,1,0)$ artinya Pertumbuhan Ekonomi (PE) berjumlah 3 lag, Penanaman Modal Dalam Negeri (PMDN) berjumlah 3 lag, Penanaman Modal Asing (PMA) berjumlah 3 lag, Ekspor (EKS) berjumlah 1 lag, dan Impor (IMP) berjumlah 0 lag (tidak ada lag).

\section{Uji stabilitas model}

Berdasarkan pengujian CUSUM ini dapat dilihat bahwa plot kuantitas tidak melewati garis batas yang ditentukan oleh tingkat signifikansi uji yaitu 5 persen dan pengujian CUSUMQ juga tidak melewati garis batas Sr yang ditentukan oleh tingkat signifikansi 5 persen. Berdasarkan grafik tersebut berarti model pertumbuhan ekonomi ini stabil dan selanjutnya dapat digunakan sebagai model untuk dianalisis.

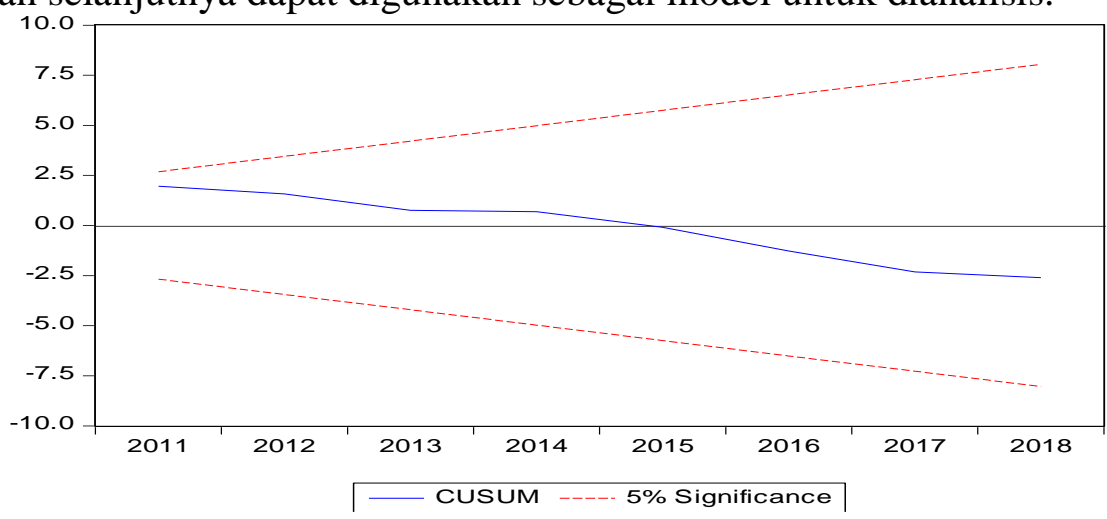

Gambar 1. Uji CUSUM 


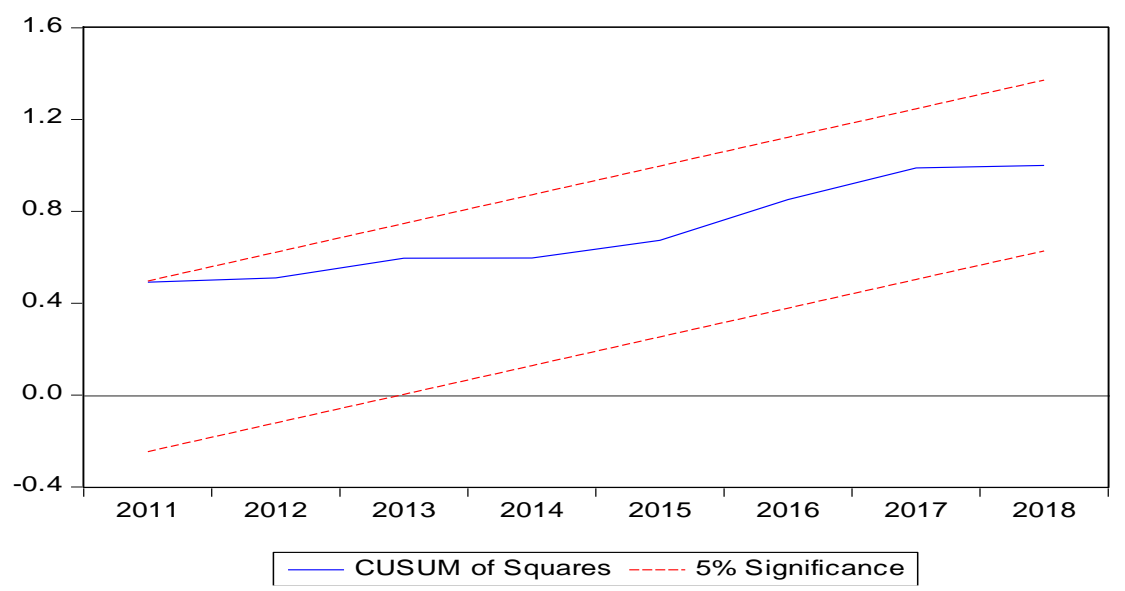

Gambar 2. Uji CUSUMQ

\section{Uji bounds test}

Uji Bounds test digunakan untuk melihat seberapa besar presentase signifikansi yang bisa kita gunakan terhadap variable yang kita teliti. Hasil uji Bounds test pada penelitian ini menunjukkan nilai $\mathrm{F}$ statistik yang nilainya cukup besar, yaitu 53.84358. Nilai ini jauh lebih besar dari batas bawah nilai pada IO dan I1. Hal ini menunjukkan bahwa hasil estimasi model ARDL bisa kita gunakan hingga signifikansi $\alpha=5 \%$, serta hasil ini juga menunjukkan bahwa antar variable memiliki hubungan kointegrasi jangka panjang.

\section{Analisis jangka pendek}

Hasil jangka pendek model ARDL dapat dilihat dari model ECM nya. Model ECM ini diperoleh dengan menggunakan metode general to specific yang diawali dari lag maksimum lalu dengan prosedur tes standar mengeliminasi variabel-variabel ARDL yang secara spesifik tidak signifikan, hingga diperoleh hasil paling sederhana (parsimonius regression). Langkah ini tidak dilakukan penulis secara manual, karena Eviews 9 yang digunakan sudah memiliki opsi ARDL, sehingga hasil yang diinginkan ini sudah otomatis didapatkan. Hasil ECM ini memiliki beberapa lag yang signifikan, namun penulis hanya akan mengambil salah satu contoh variable sebagai gambaran umum estimasi jangka pendek.

Berdasarkan estimasi Tabel 4 menunjukkan bahwa variabel Penanaman Modal Dalam Negeri (PMDN) memiliki hasil signifikan dan negatif terhadap pertumbuhan ekonomi provinsi Jambi, variabel Ekspor (EKS) dan Impor (IMP) memiliki hasil tidak signifikan dan positif terhadap pertumbuhan ekonomi provinsi Jambi, sedangkan Penanaman Modal Asing (PMA) memiliki hasil signifikan dan positif terhadap pertumbuhan ekonomi provinsi Jambi.

Tabel 4. Model jangka pendek

\begin{tabular}{ccccc}
\hline Variabel & Coefficient & Std. Error & t-Statistic & Probabilitas \\
\hline D(PMDN) & $-0,000000$ & 0,000000 & $-1,948136$ & 0,0872 \\
D(PMA) & 0.000003 & 0,000001 & 3,012098 & 0,0168 \\
D(EKS) & 0,000002 & 0,000001 & 2,110592 & 0,0678 \\
D(IMP) & 0,000002 & 0,000005 & 0,439815 & 0,6717 \\
CointEq(-1) & $-0,965522$ & 0,142718 & $-6,765260$ & 0,0001 \\
\hline
\end{tabular}

Sumber: Data diolah, 2020 


\section{Analisis jangka panjang}

Estimasi jangka panjang merupakan hal yang diunggulan dalam penggunaan model ARDL. Dengan menggunakan model ini, kita bisa menganalisis hubungan jangka panjang ketika variabel variabel penjelasnya campuran antara yang bersifat I(1) dan I(0). Estimator ARDL akan meghasilkan koefisien jangka panjang yang konsisten dimana estimasi yang dihasilkan konsisten dengan koefisien jangka panjang yang bagus tanpa peduli apakah variabel-variabel penjelasnya atau regresornya $\mathrm{I}(0)$ ataupun $\mathrm{I}(1)$. Estimasi Jangka Panjang ARDL dari tabel diatas menunjukkan bahwa variabel Penanaman Modal Dalam Negeri (PMDN) dan Ekspor (EKS) memiliki hasil signifikan dan positif terhadap Pertumbuhan Ekonomi (PE). Sedangkan variabel Penanaman Modal Asing (PMA) memiliki nilai yang negatif namun signifikan serta variabel Impor (IMP) memiliki nilai yang positif namun tidak signifikan

Tabel 5. Hasil jangka panjang ARDL

\begin{tabular}{lcccc}
\hline \multicolumn{1}{c}{ Variabel } & Coefficient & Std. Error & t-Statistic & Probabilitas \\
\hline PMDN & 0.000001 & 0.000000 & 3.891405 & 0.0046 \\
PMA & -0.000014 & 0.000003 & -3.952073 & 0.0042 \\
EKS & 0.000003 & 0.000001 & 3.141448 & 0.0138 \\
IMP & 0.000002 & 0.000005 & 0.451723 & 0.6635 \\
C & 0.667960 & 0.920100 & 0.725965 & 0.4886 \\
\hline
\end{tabular}

Sumber : Data diolah, 2020

\section{KESIMPULAN DAN SARAN}

\section{Kesimpulan}

Perkembangan rata-rata pertumbuhan ekonomi provinsi Jambi yang digambarkan oleh PDRB atas harga konstan tahun selama tahun 1993-2018 mengalami peningkatan setiap tahunnya sebesar 23,37 persen. Perkembangan rata-rata PMDN provinsi Jambi yang direalisasikan selama tahun 1993-2018 sebesar 11,1 persen. Perkembangan ratarata PMA provinsi Jambiyang direalisasikan dari tahun 1993-2018 cenderung fluktuatif dengan nilai sebesar 475 persen. Perkembangan ekspor provinsi Jambi tahun 1993-2018 mengalami fluktuatif setiap tahunnya dengan rata-rata sebesar 9,71 persen. Dan Perkembangan rata-rata impor provinsi Jambi selama tahun 1993-2018 sebesar 43,48 persen.

Selama periode penelitian dalam jangka pendek PMDN berpengaruh negatif signifikan terhadap pertumbuhan ekonomi. PMA berpengaruh positif dan signifikan terhadap pertumbuhan ekonomi. Ekspor dan Impor berpengaruh positif tetapi tidak signifikan terhadap pertumbuhan ekonomi. Dan selama periode penelitian jangka panjang PMDN berpengaruh positif dan signifikan terhadap pertumbuhan ekonomi. PMA berpengaruh negatif dan signifikan terhadap pertumbuhan ekonomi. Variabel ekspor berpengaruh positif dan signifikan terhadap pertumbuhan ekonomi. Dan imor berpengaruh positif tetapi tidak signifikan terhadap pertumbuhan ekonomi.

\section{Saran}

Dalam upaya meningkatkan pertumbuhan ekonomi provinsi Jambi, maka indikator makro ekonomi harus ditingkatkan. Seperti meningkatkan Penanaman Modal Dalam Negeri (PMDN), Penanaman Modal Asing (PMA), ekspor serta menurunkan impor. Serta diharapkan pertumbuhan ekonomi terus meningkat dari tahun ke tahunnya maka pemerintah harus berperan penting dalam rangka meningkatkan kegiatan ekonomi 
yang memiliki potensi-potensi yang ada. Serta diharapkan pemerintah memudahkan para penanam modal dalam menanamkan modalnya di suatu daerah dengan proses perizinan yang mudah sehingga para investor lokal maupun luar negeri tertarik untuk berinvestasi di provinsi Jambi ini. Hal ini akan membuat pemerintah dapat memantau kegiatan investasi yang dijalankan oleh investor.

\section{DAFTAR PUSTAKA}

Amir, Amri., Junaidi, Yulmardi. (2009). Metodologi Penelitian dan Penerapannya. IPB Press: Bogor.

Amir,Amri. (2007). Perekonomian Indonesia (dalam persefektif makro). Biografika: Bogor.

Arfa, Ipa Jamiati. (2015). Pengaruh Perdagangan dan Penanaman Modal Asing Terhadap Pertumbuhan Ekonomi di Indonesia: Sebuah Aplikasi Autoregressive Distributed Lag Model (ARDL). Tesis. Fakultas Ekonomi. Universitas Syiah Kuala: Aceh.

Arsyad,Lincolin. (2010). Ekonomi Pembangunan. YKPN: Yogyakarta.

Astuti,Ismadiyanti Purwaring, Ayuningtyas,Fitri Juniwati. (2018). Pengaruh Ekspor dan Impor Terhadap Pertumbuhan Ekonomi di Indonesia. Jurnal Ekonomi dan Pembangunan, 19 (1): 1-10.

Ayu, A., Rahayu, S., \& Junaidi. (2020). Pengaruh Kinerja Keuangan Terhadap Pertumbuhan Ekonomi Dengan Alokasi Belanja Modal Sebagai Variabel Intervening. Jurnal Akuntansi \& Keuangan Unja, 5(1), 31 - 44

Badan Pusat Statistik Provinsi Jambi. (2000-2019). Jambi Dalam Angka berbagai edisi. BPS Provinsi Jambi: Jambi

Gujarati, Damodar N. (2015). Ekonometrika Dasar. Erlangga: Jakarta.

Haryadi. (2013). Ekonomi Internasional Teori dan Aplikasi. Biografika: Bogor.

Nuraini. (2016). Analisis Pengaruh Investasi Penanaman Modal dalam Negeri (PMDN) dan Investasi Penanaman Modal Asing (PMA) Terhadap Pertumbuhan Ekonomi di Provinsi Jambi. Jurnal Ilmiah Universitas Batanghari Jambi, 16 (1), 88-92.

Sukirno,Sadono. (2011). Teori Pengantar Makro Ekonomi. Rajawali Pers: Jakarta.

Zamzami,Z., Hastuti,D., \& Sunargo. (2020). Pengaruh ekspor Asia Timur terhadap pengangguran di Indonesia, Jurnal Paradigma Ekonomika, 15 (1), 59-74 